\title{
Статеві відмінності в електричній активності головного мозку людини під час тестування асоціативної пам'яті
}

В ЕЕГ-обстеженні взяли участь 40 людей (20 жінок і 20 чоловіків). У результаті встановлено, що асоціативне запам'ятовування слів у жінок відбувалося здебільшого із залученням задньої асоціативної кори, причому найбільш складними виявились асоціації, суміжні за часом. Чоловіки здійснювали запам'ятовування за рахунок уявлення та проговорювання тестових слів.

Ключові слова: асоціативна пам'ять, ЕЕГ, активність головного мозку, вербальні асоціації за схожістю, вербальні асоціації за суміжністю.

Постановка наукової проблеми та її значення. Здатність відновлювати інформацію та утримувати іiі в пам'яті - критична для цілеспрямованої діяльності. Тому в багатьох роботах досліджується оперативна пам'ять, у якій інформація зберігається в активному стані. У 1972 р. Ендель Талвінг запропонував термін епізодичної пам'яті, щоб визначити форму пам'яті, яка дає змогу пов'язати багато різних типів інформації в просторово-часовий контекст. На сьогодні виділяють асоціативні та стратегічні компоненти епізодичного буферу або епізодичної пам'яті [4]. При запам'ятовуванні інформації в епізодичному буфері об'єднується велика кількість взаємопов'язаних елементів, але механізми такого об'єднання ще недостатньо вивчено. Показано, що жінки перевершують чоловіків у вербальних здібностях, у той час як чоловіки краще володіють невербальною епізодичною пам'яттю й набагато краще розв'язують візуально-просторові завдання [6].

Відомо, що асоціації лежать в основі когнітивних процесів. Залежно від умов, необхідних для їх утворення, асоціації поділяють на різні типи: асоціації за схожістю, асоціації за суміжністю (за часом i простором), причому базовими $\epsilon$ асоціації за схожістю [1]. Асоціації за схожістю бачимо тоді, коли в мозку відображаються зв'язки між предметами, які схожі в певному відношенні. Асоціації за суміжністю поєднують два явища, пов'язані в часі чи просторі [1].

Дослідження за допомогою функціональної магнітно-резонансної терапії томографії (фМРТ) показало, що обробка більшості асоціативних компонент підтримується сенсорними областями та середньою скроневою долею (MTL), а процеси уваги та організаційні - префронтальною корою (PFC). Головна функція MTL та гіпокампу полягає у зв' язуванні різних особливостей епізодів у цілісне уявлення й у закріпленні цього уявлення у взаємодії із сенсорно визначеною корою та асоціативними ділянками задньотім'яної кори. Проте ділянки PFC залучені до процесів уваги та оптимізації формування об'єктів пам'яті за рахунок вибору, уточнення й організації семантичних і контекстних особливостей епізоду $[3,5,7-10,12]$. Такі результати отримано при пред’явленні обстежуваним різних зображень, але на сьогодні все ще відкритим залишається питання про статеві особливості процесу створення та обробки вербальних асоціацій різних типів.

Мета роботи - дослідити активність головного мозку при запам’ятовуванні асоціацій різного типу в чоловіків і жінок.

Матеріали та методи досліджень. У дослідженні як обстежувані взяли участь 40 осіб (20 жінок та 20 чоловіків віком 21 \pm 3 рік, правші), студенти 1-5 курсів Київського національного університету імені Тараса Шевченка. Обстежувані проходили такі комп'ютерні субтести: «Асоціації за схожістю» (АСX), «Асоціації за суміжністю за часом» (АСХЧ) та «Асоціації за суміжністю за простором» (АСХПР). Під час проходження субтесту ACX на екрані монітора обстежуваному пред'являли 15 пар слів, які він повинен був запам'ятати за 40 с. Через 1 хв після того, як слова на екрані згасали, у верхньому прямокутнику послідовно з'являлися перші слова пар. Завдання обстежуваного - не більше ніж за 60 с знайти номер слова, що відповідає парі. Далі обстежувані проходили субтести АСХЧ й АСХПР, у кожному з яких за 40 с треба було запам'ятати вісім слів, зв'язаних у певній послідовності за часом та простором. Через 1 с після того, як ці слова згасали, на екрані 'являлася множина слів, серед яких треба було знайти тестові слова й розмістити їх у відповідній послідовності, витративши на це не більше ніж 60 с.

В усіх обстежуваних реєстрували електроенцефалограму (ЕЕГ) до початку обстеження (проба із заплющеними та розплющеними очима) і під час проведення тестування. Для реєстрації та аналізу ЕЕГ використовували комплекс «Нейрон-Спектр-4/ВП» (ЕС-сертифікат № RQ043131-V від 08.11.2004p). Запис

(C) Мавроматі Т., Філімонова Н., Зима I., 2015 
ЕЕГ здійснювали монополярно, референтний електрод розміщено на мочці вуха з кожної сторони, частота квантування ЕЕГ дорівнювала 500 Гц. Застосовано мостикові посріблені електроди, які накладалися за міжнародною системою «10-20 \%» у 19 стандартних відведеннях. У кожному відведенні для частотних діапазонів ЕЕГ- дельта (0,5-3,9 Гц), тета (4,0-7,9 Гц), ), альфа1 (8,0-9,4 Гц), альфа 2 (9,5-10,5 Гц) та альфа 3 (10,6-12,9 Гц) за допомогою програми «Нейрон-Спектр» обчислювали повну потужність спектра у відповідних відведеннях $-\mathrm{S}_{\text {повна, }}$ мк $\mathrm{B}^{2} / \mathrm{c}^{2}$.

Статистичний аналіз даних проводили за допомогою пакета STATISTICA 8.0 (StatSoft, USA, 2008). Нормальність розподілів змінних перевіряли тестом Шапіро-Вілка. Оскільки розподіл практично всіх параметрів за критерієм Шапіро-Вілка відрізнявся від нормального ( $<0,05)$, для порівняння груп використано критерій Манна-Вітні. Дані в тексті представлено у вигляді медіани $\left(\mathrm{M}_{\mathrm{e}}\right)$ i нижнього (25 \%) та верхнього (75 \%) квартилей: $\mathrm{M}_{\mathrm{e}}[25 \% ; 75 \%]$.

Виклад основного матеріалу й обгрунтування отриманих результатів дослідження. Асоціації за схожістю. $\mathrm{S}_{\text {повна }} \delta$-діапазону у лівій фронтальній ділянці у відведенні F7A1 (рис. 1) виявилися значуще меншими в жінок - 26,00 [17,50;39,50] мкВ ${ }^{2} \mathrm{c}^{2}$, порівняно з чоловіками, - 40,00 [26,50; 62,50] мк $\mathrm{B}^{2} / \mathrm{c}^{2}$

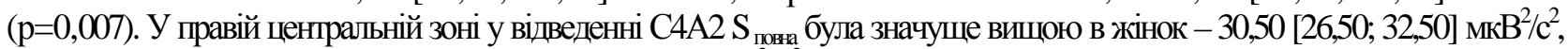
порівняно з чоловіками, - 23,50 [20,50; 30,50] мкВ ${ }^{2} \mathrm{c}^{2} \quad(\mathrm{p}=0,03)$. У центральній тім'яній зоні у відведенні

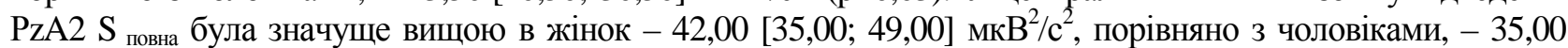
$[28,50 ; 42,00]$ мкB $^{2} / \mathrm{c}^{2}(\mathrm{p}=0,03)$. У правій тім' яній зоні у відведенні $\mathrm{P} 4 \mathrm{~A} 2 \mathrm{~S}_{\text {повна значуще вища в жінок - } 32,00}$ $[26,50 ; 34,00] \mathrm{M \kappa B}^{2} / \mathrm{c}^{2}$, порівняно з чоловіками, - 25,00 [22,50; 29,50] мкB $\mathrm{c}^{2}(\mathrm{p}=0,009)$. Оскільки в [10] показано, що в основі феномену активного інформаційного відбору на рівні первинної сенсорної кори головного мозку лежать нейронні коливання в $\delta$-діапазоні, значуще вища електрична активність мозку чоловіків у $\delta$-діапазоні в лівій фронтальній зоні, порівняно з жінками, свідчила про активацію в чоловіків специфічних процесів відбору вербальної вхідної інформації із залученням зони Брока, що свідчило про запам' ятовування пар слів за рахунок їх проговорювання. Значуще вища активність у правій тім' яній зоні в жінок, порівняно з чоловіками, свідчила про направлення інформаційного потоку в праву сомато-сенсорну асоціативну кору, яка залучена до запам'ятовування асоціативно-пов'язаних зображень, що показано методом фМРТ [4]. Отже, можна припустити, що при запам'ятовуванні в жінок відбувалася візуалізація вербальних асоціативних пар. Крім того, підвищена активність у задній сингулярній корі в жінок, порівняно з чоловіками, наймовірніше, свідчила про вищу інтермодальну взаємодію при запам'ятовуванні асоціацій за схожістю в жінок.

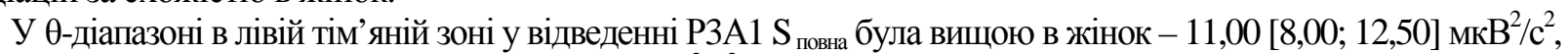
порівняно з чоловіками, - 7,90 [5,15;9,15] мкВ ${ }^{2} \mathrm{c}^{2}(\mathrm{p}=0,004)$. У нижній скроневій ділянці у відведенні $\mathrm{T} 5 \mathrm{~A} 1 \mathrm{~S}_{\text {повна }}$ вища в жінок - 8,95 $[6,25 ; 11,50]$ мкB $^{2} / \mathrm{c}^{2}$, порівняно з чоловіками, $-5,55[4,85 ; 7,95] \mathrm{M \kappa B}^{2} / \mathrm{c}^{2}$ $(\mathrm{p}=0,006)$. Добре відомо, що коливання в $\theta$-діапазоні важливі для багатьох пізнавальних функцій. Низку пейсмейкерів коливань у $\theta$-діапазоні виявлено в середній і бічних частинах септуму, гіпоталамусі, гіпокампі, ретикулярній формації та в стовбурі мозку [5]. Активність в $\theta$-діапазоні асоціюють 3 успішним кодуванням інформації при запам'ятовуванні, утримуванні інформації в пам'яті та 3 епізодичною пам'яттю [11]. В [11] методом фМРТ показано, що для асоціативного запам'ятовування зорових стимулів (зображень) залучаються середні структури скроневої долі. Отже, отримані нами результати узгоджуються з результатами [11], однак, оскільки в наших дослідах запам'ятовувалися пари слів, а не зображень, виявлено підвищену активність не в середній скроневій, а - в лівій задньоскроневій долі, яка пов'язана із зоною Верніке. Спираючись на результати [12], можна припустити, що жінки залучали здебілышого слухову пам'ять до асоціативного зв'язування вербальної інформації: аналізу складних слів і конструювання відношень між словами. Підвищена активність у лівій півкулі в зоні скронево-тім' яно-потиличного з'єднання (зона ТРО), яку відносять до образної асоціативної кори [2], у жінок, порівняно з чоловіками, можливо, свідчила про включення цієї зони в процес створення вербальних крос-модальних асоціацій під час виконання ними тесту АСX.

У [5] виділено три $\alpha$-діапазони: $\alpha 1$ (8-9,5 Гц) та $\alpha 2$ (9,5-10,5 Гц), $\alpha 3$ (10,5-12 Гц). Активність в $\alpha 1-$ діапазоні, яка є функціонально близькою до $\theta$, відповідає за специфічну увагу і є локальною. Активність в a2-діапазоні більш індивідуальна, слугує маркером ефективності виконання завдання та є ще більш локальною. На сьогодні вважається, що активність в $\alpha 3$-діапазоні відповідає за семантичний аналіз інформації в оперативній пам'яті. В $\alpha 1$-діапазоні в нижній скроневій ділянці у відведенні T5A1 S повна була значуще вищою в жінок - 2,10 [1,50;3,40] мк $\mathrm{B}^{2} / \mathrm{c}^{2}$, порівняно з чоловіками, - 1,20 [0,92; 1,85] мкB $/ \mathrm{c}^{2}(\mathrm{p}=0,04)$, що свідчило про залучення зони Верніке до процесу запам'ятовування пар слів. В $\alpha 2$-діапазоні в правій

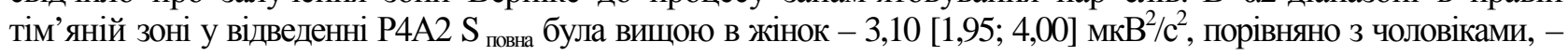


$1,85[1,50 ; 3,10]$ мк $\mathrm{B}^{2} / \mathrm{c}^{2},(\mathrm{p}=0,009)$, що свідчило про те, що в жінок ефективне запам'ятовування пар слів потребувало створення не лише вербальних асоціацій, а й зорових (образних абстракцій [2]). В $\alpha 3-$ діапазоні в нижній скроневій ділянці у відведенні T5A1 $\mathrm{S}_{\text {повна }}$ була значуще вищою в жінок - 3,10 [1,85; $4,90]$ мкB $^{2} / \mathrm{c}^{2}$, порівняно з чоловіками, - $1,80[1,35 ; 2,75] \mathrm{m \kappa B}^{2} / \mathrm{c}^{2}(\mathrm{p}=0,02)$, що свідчило про те, що в жінок, порівняно з чоловіками, у семантичний аналіз здебільшого залучена зона Верніке.

Отже, можна припустити, що запам' ятовування асоціацій за схожістю в жінок відбувалось із залученням слухової пам'яті, семантичного аналізу, інтермодальних взаємодій та створення зорових образів асоціативних пар слів, у той час, як чоловіки запам' ятовували пари слів за допомогою їх проговорювання.
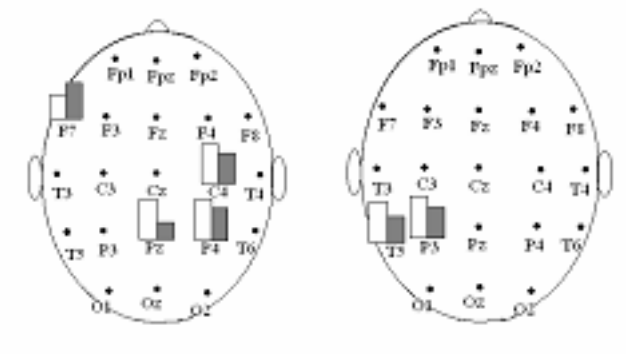

$\delta$-діапазон

ө-діапазон

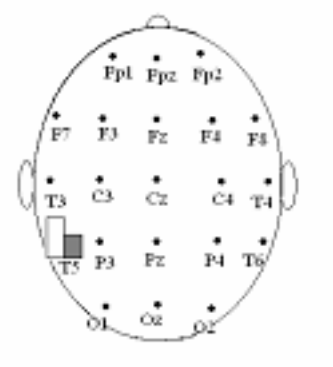

a1-діапазон

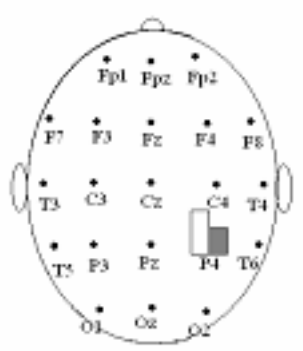

а2-діапазон

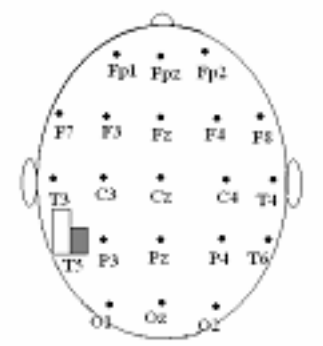

$\alpha 3$-діапазон

Умовні позначення:

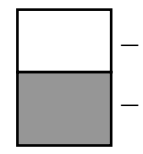

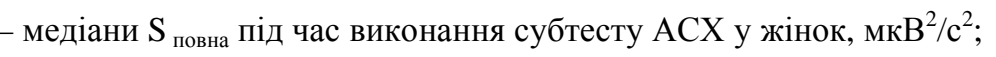

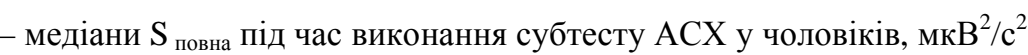

Рис. 1. Значущі відмінності в активності головного мозку жінок $і$ чоловіків при виконанні субтесту АСX $(n=40), p<0,05$

\section{Асоиіації за суміжністю за часом}

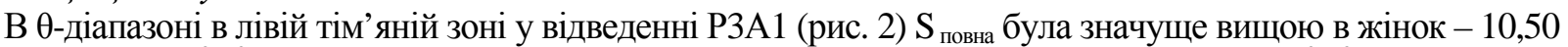
$[8,65 ; 14,50] \mathrm{м \kappa}^{2} / \mathrm{c}^{2}$, порівняно 3 чоловіками, і вища в жінок $-8,00[4,80 ; 16,50] \mathrm{M \kappa B}^{2} / \mathrm{c}^{2}$, порівняно 3 чоловіками, $-6,05[4,35 ; 8,20] \mathrm{M \kappa B}^{2} / \mathrm{c}^{2}(\mathrm{p}=0,04)$. У лівій потиличній ділянці у відведенні O1A1 $\mathrm{S}_{\text {повна значуще }}$ вища в жінок $-11,50[6,25 ; 15,50]$ мкB $^{2} / \mathrm{c}^{2}$, якщо їх порівнювати 3 чоловіками, $-6,20[3,90 ; 12,00] \mathrm{м \kappa B}^{2} / \mathrm{c}^{2}$ $(\mathrm{p}=0,03)$. Це свідчило про формування в жінок специфічної мережі в лівій півкулі із залученням зон ТРО та Верніке для запам'ятовування асоціацій, суміжних за часом.

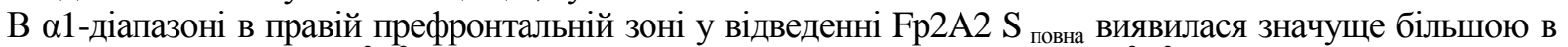
жінок $-2,45[1,75 ; 3,70]$ мкВ $^{2} / \mathrm{c}^{2}$, порівняно 3 чоловіками, $-1,70[1,30 ; 2,00] \mathrm{m \kappa}^{2} / \mathrm{c}^{2}(\mathrm{p}=0,01)$. У лівій тім'яній

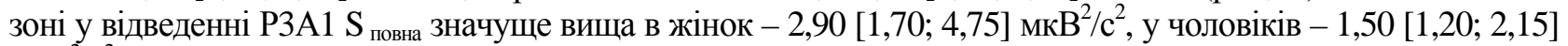

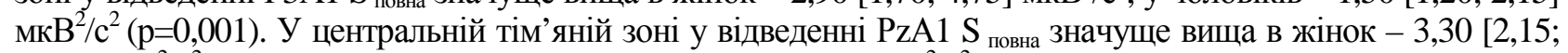
$5,05]$ мк $\mathrm{B}^{2} / \mathrm{c}^{2}$, порівняно 3 чоловіками, - $2,10[1,55 ; 2,95]$ мкB$^{2} / \mathrm{c}^{2}(\mathrm{p}=0,01)$. У нижній скроневій ділянці у

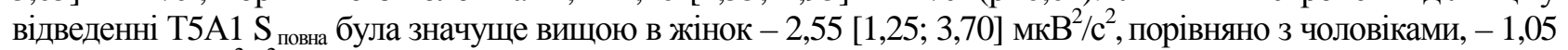
$[0,84 ; 1,70]$ мкВ $\mathrm{B}^{2} \mathrm{c}^{2}(\mathrm{p}=0,003)$. У лівій потиличній ділянці у відведенні O1A1 $\mathrm{S}_{\text {повна }}$ значно вища в жінок $-3,00$ $[1,55 ; 4,35]$ мкB $^{2} / \mathrm{c}^{2}$ (у чоловіків - $\left.1,70[1,20 ; 2,35] \mathrm{m \kappa}^{2} / \mathrm{c}^{2}\right)(\mathrm{p}=0,04)$. Вища активність у жінок в $\alpha 1$-діапазоні, порівняно з чоловіками, у правій префронтальній зоні свідчила про образну обробку вербальної інформації, а вища активність у ділянках задньої асоціативної кори лівої півкулі - про інтермодальні взаємодії. 


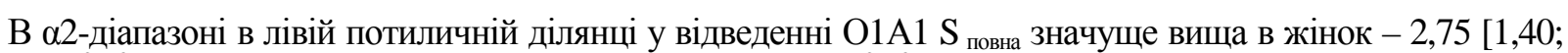
$5,70]$ мк $\mathrm{B}^{2} / \mathrm{c}^{2}$, порівняно $з$ чоловіками, $-1,80[1,10 ; 2,80]$ мк $\mathrm{B}^{2} / \mathrm{c}^{2}(\mathrm{p}=0,04)$ та в правій фронтальній ділянці у відведенні F4A2 $\mathrm{S}_{\text {повна }}-2,15[1,50 ; 4,15]$ мкB $^{2} / \mathrm{c}^{2}$, порівняно 3 чоловіками, $-1,55[0,95 ; 2,40] \mathrm{M \kappa B}^{2} / \mathrm{c}^{2}(\mathrm{p}=0,04)$, що свідчить про необхідність створення зорових образів пред’явлених пар слів для їх ефективного запам'ятовування жінками.

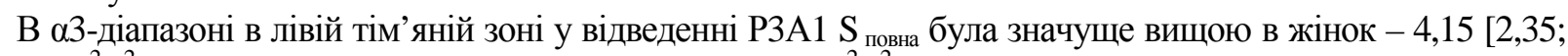
$6,85]$ мк $\mathrm{B}^{2} / \mathrm{c}^{2}$, порівняно $з$ чоловіками, $-2,20[1,65 ; 3,70] \mathrm{м \kappa}^{2} / \mathrm{c}^{2}(\mathrm{p}=0,005)$. У правій тім'яній зоні у відведенні $\mathrm{P} 4 \mathrm{~A} 2 \mathrm{~S}_{\text {повна }}$ була значуще вища в жінок - $3,95[2,40 ; 5,55]$ мкВ $/ \mathrm{c}^{2}$, у чоловіків $-2,45[1,50 ; 3,80]$ мкB $^{2} / \mathrm{c}^{2}$

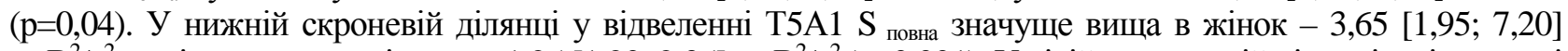
$\mathrm{м \kappa}^{2} / \mathrm{c}^{2}$, порівняно з чоловіками, $-1,25[1,20 ; 2,35]$ мкВ $^{2} / \mathrm{c}^{2}(\mathrm{p}=0,001)$. У лівій потиличній ділянці у відведенні

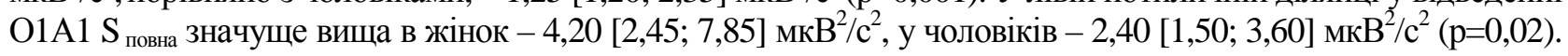
У правій потиличній ділянці у відведенні О2A2 S S повна була значуще вищою в жінок $-4,55[2,75 ; 7,20]$ мкB $^{2} / \mathrm{c}^{2}$, порівняно 3 чоловіками, $-3,15[1,90 ; 3,55] \mathrm{m \kappa B}^{2} / \mathrm{c}^{2}(\mathrm{p}=0,03)$. Вища активність у задніх асоціативних ділянках обох півкуль в $\alpha 3$-діапазоні у жінок свідчила про те, що вони, на відміну від чоловіків, при запам'ятовуванні асоціацій, що суміжні за часом, задіяли семантичний аналіз як образної, так і вербальної інформації.

Отже, запам'ятовування асоціацій, суміжних за часом, у жінок потребувало залучення задньої асоціативної кори обох півкуль.

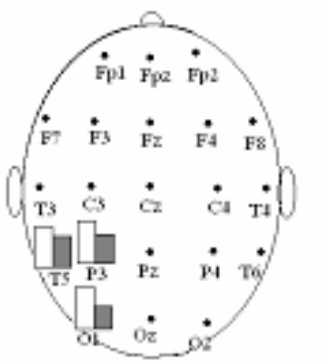

ө-діапазон

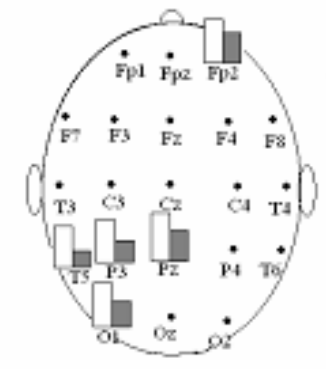

$\alpha 1$-діапазон

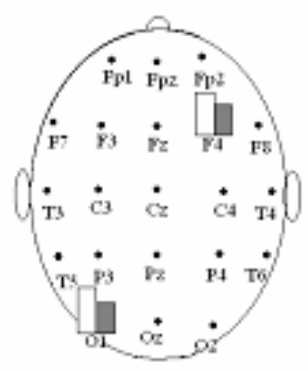

а2-діапазон

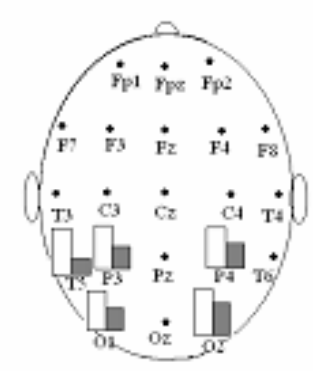

а3-діапазон

Умовні позначення:

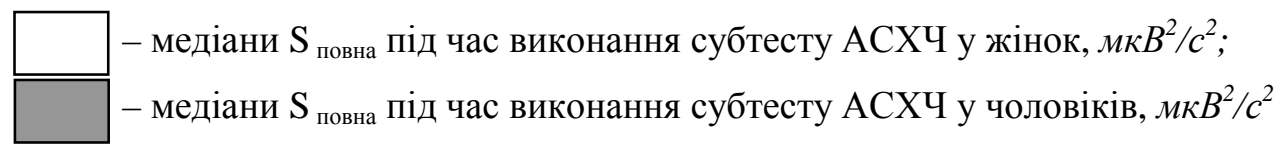

Рис. 2. Значущі відмінності в активності головного мозку жінок і чоловіків при виконанні субтесту $A C X Y(n=40), \quad p<0,05$

Асоиіації за суміжністю за простором

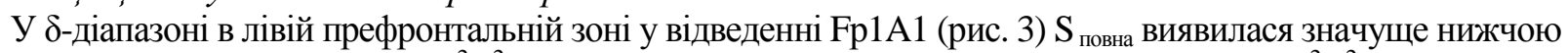
в жінок - 58,00 [39,00; 81,00] мкВ ${ }^{2} / \mathrm{c}^{2}$, порівняно з чоловіками, $-99,50[70,50 ; 133,50] \mathrm{м \kappa B}^{2} / \mathrm{c}^{2}(\mathrm{p}=0,006)$. У

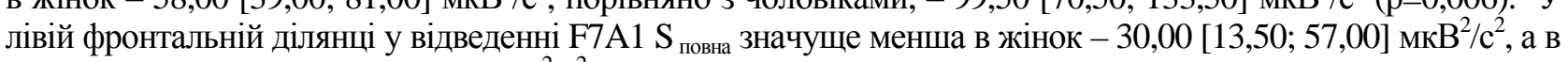
чоловіків - 48,00 [32,50; 64,00] мкB2 $/ \mathrm{c}^{2}(\mathrm{p}=0,03)$. У правій фронтальній ділянці у відведенні $\mathrm{F} 8 \mathrm{~A} 2 \mathrm{~S}$ повна виявилася значуще меншою в жінок - $27,50[19,50 ; 39,00]$ мкВ $/ \mathrm{c}^{2}$, порівняно 3 чоловіками, $-39,50$ [28,50; $53,00]$ мк $^{2} / \mathrm{c}^{2}(\mathrm{p}=0,04)$. Значуще вища електрична активність мозку чоловіків, порівняно 3 жінками, у $\delta$-діапазоні в лівих фронтальній і префронтальній зонах та в правій фронтальній зоні та свідчила про те, що вони формували специфічний інформаційний потік.

У $\theta$-діапазоні в правій фронтальній ділянці у відведенні F4A2 $\mathrm{S}_{\text {повна }}$ виявилася значуще вищою в жінок $18,00[7,40 ; 23,50] \mathrm{м \kappa B}^{2} / \mathrm{c}^{2}$, порівняно з чоловіками, - $8,55[6,95 ; 11,00] \mathrm{м \kappa B}^{2} / \mathrm{c}^{2}(\mathrm{p}=0,02)$, що свідчило про включення образної уяви, оскільки саме цю ділянку пов'язують з епізодичним буфером оперативної пам'яті.

$\mathrm{B} \alpha 1$-діапазоні в лівій тім'яній зоні у відведенні $\mathrm{P} 3 \mathrm{~A} 1 \mathrm{~S}_{\text {повна }}$ була значуще вищою в жінок $-2,50$ $[1,95 ; 4,35]$ мкВ $^{2} / \mathrm{c}^{2}$, у чоловіків - $1,75[1,10 ; 2,70] \mathrm{м \kappa}^{2} / \mathrm{c}^{2}(\mathrm{p}=0,01)$. У центральній тім'яній зоні у відведенні PzA1 S повна значуще вища в жінок - $3,65[2,05 ; 5,35]$ мкB $^{2} / \mathrm{c}^{2}$, порівняно 3 чоловіками, $-2,15[1,55 ; 2,85]$ $\mathrm{M \kappa B}^{2} / \mathrm{c}^{2}(\mathrm{p}=0,01)$. У лівій потиличній ділянці у відведенні O1A1 $\mathrm{S}_{\text {повна }}$ була значуще вищою в жінок $-2,70$ $[2,00 ; 4,40] \mathrm{м \kappa B}^{2} / \mathrm{c}^{2}$, порівняно з чоловіками, $-1,95[1,65 ; 2,35] \mathrm{м \kappa B}^{2} / \mathrm{c}^{2}(\mathrm{p}=0,01)$. Підвищена активність у цих 
ділянках у жінок свідчила про виникнення зорових образів при запам'ятовуванні слів, пов'язаних із просторовими характеристиками.

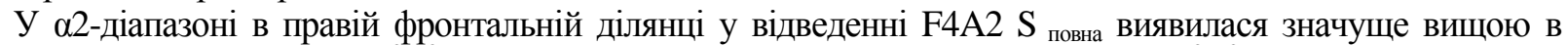
жінок - 2,95 $[1,30 ; 4,70]$ мкB $^{2} / \mathrm{c}^{2}$, порівняно з чоловіками, $-1,45[1,00 ; 2,00]$ мкВ $\mathrm{B}^{2} \mathrm{c}^{2}(\mathrm{p}=0,005)$. У нижній

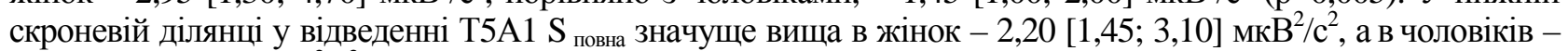
$1,30[0,65 ; 2,45] \mathrm{мкB}^{2} / \mathrm{c}^{2}(\mathrm{p}=0,04)$. Отже, для жінок ефективність запам'ятовування просторових асоціацій грунтувалася на використанні епізодичного буферу та зони Верніке, що відповідає за усвідомлення змісту слів.

$\mathrm{B} \alpha 3$-діапазоні в правій фронтальній ділянці у відведенні $\mathrm{F} 4 \mathrm{~A} 2 \mathrm{~S}$ повна виявилася значуще вищою в

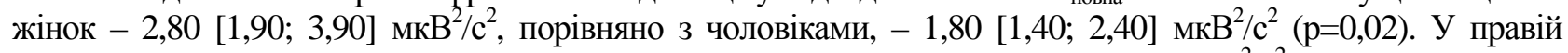

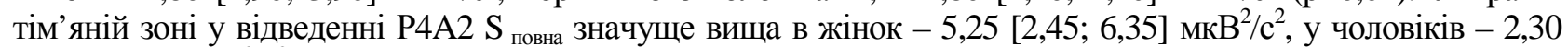

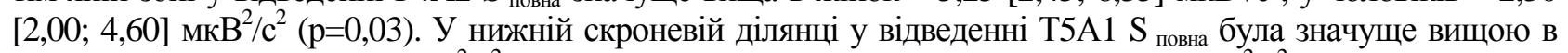
жінок - 3,35 $[1,75 ; 4,65]$ мкВ $\mathrm{c}^{2} \mathrm{c}^{2}$, порівняно $з$ чоловіками, $-1,60[1,25 ; 2,60] \mathrm{M \kappa B}^{2} / \mathrm{c}^{2}(\mathrm{p}=0,02)$. Отже, у семантичному аналізі просторової інформації в жінок задіяно асоціативні ділянки обох півкуль.

Тобто можна припустити, що запам'ятовування асоціацій за суміжністю за простором у чоловіків відбувалося фактично за допомогою механізмів їх уявлення та проговорювання, на відміну від жінок, які, зі свого боку, запам'ятовували вказану інформацію за допомогою як їі образного уявлення, так і вербального семантичного аналізу.

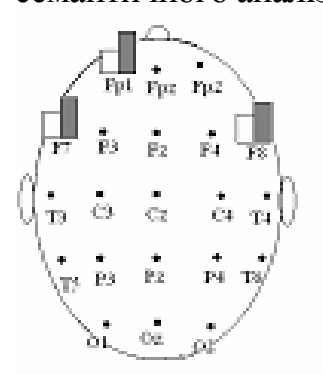

$\delta$-діапазон

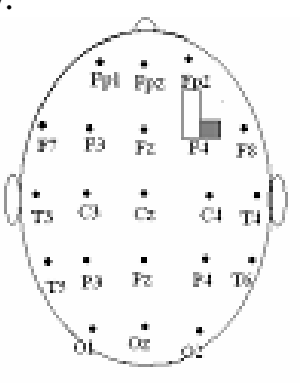

ө-діапазон

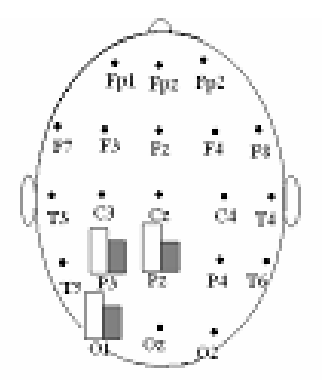

$\alpha 1$-діапазон

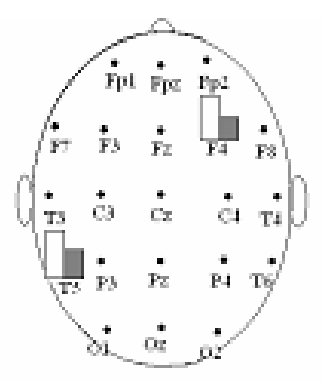

a2-діапазон

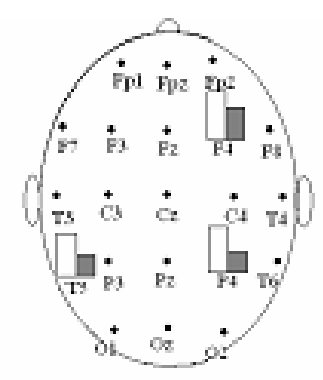

а3-діапазон

Умовні позначення:

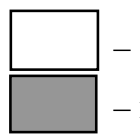

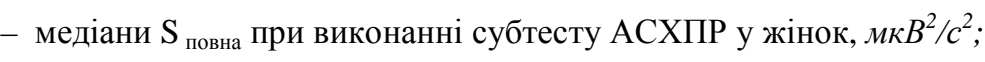

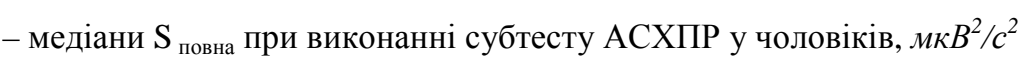

Рис. 3. Значущі відмінності в активності головного мозку жінок і чоловіків при виконанні субтесту АСХПР $(n=40), \quad p<0,05$

Висновки й перспективи подальшого дослідження. Асоціативне запам'ятовування слів у жінок відбувалося здебільшого із залученням задньої асоціативної кори, причому найбільш складними виявились асоціації, суміжні за часом. Чоловіки здійснювали запам'ятовування за рахунок уявлення та проговорювання тестових слів.

\section{Джерела та література}

1. Бэн А. Основные направления психологии в классических трудах. Ассоциативная психология // Эббингауз Г. Очерк психологии / А. Бэн. - М. : ООО «Изд-во АСТ - ЛТД», 1998. - С. 362-544.

2. Рамачандран В. Рождение разума / В. Рамачандран. - М. : Олимп-Бизнес, 2006. - 224 с.

3. Hales J. B. The timing of associative memory formation: frontal lobe and anterior medial temporal lobe activity at associative binding predicts memory / J. B. Hales, J. B. Brewer // Journal of neurophysiology. 2011. - V.105 (4). - P. 1454-1463.

4. Kahana M. Associative Retrieval Processes in Episodic Memory / M. Kahana, M. W. Howard, S. M. Polyn // Cognitive Psychology of Memory. - 2008. - V. 2. - P. 1-24.

5. Klimesch W. Eeg alpha and theta oscillations reflect cognitive and memory performance / W. Klimesch // Brain Research Reviews. - 1999. - V. 29 (2-3). - P. 169-195.

6. Lewin C. Sex Differences in Memory and Other Cognitive Abilities / Lewin Catharina // Department of Psychology, Stockholm University. Doctoral Dissertation. - 2003. - P. 1-60.

7. Preminger S. Stimulus-free thoughts induce differential activation in the human default network / S. Preminger, T. Harmelech, R. Malach // NeuroImage. - 2011. - V. 54 (2). - P. 1692-1702. 
8. Repov Š. The multi-component model of working memory: Explorations in experimental cognitive psychology / Š. Repov, A. Baddeley // Neuroscience. - 2006. - V. 139, Is. 1. - P. 5-21.

9. Sauseng P. What does phase information of oscillatory brain activity tell us about cognitive processes? / P. Sauseng, W. Klimesch // Neuroscience \& Biobehavioral Reviews. - 2008. - V. 32 (5). - P. 1001-1013.

10. Schroeder C. Low-frequency neuronal oscillations as instruments of sensory selection / C. Schroeder, P. Lakatos // Trends in Neurosciences. - 2009. - V. 32 (1). - P. 9-18.

11. Theta synchronization during episodic retrieval: neural correlates of conscious awareness / W. Klimesch, M. Doppelmayr, A. Yonelinas, N. Kroll, M. Lazzara, D. RoËhm, W. Gruber // Cogn. Brain Res. - 2001b. V.12. - P. 33-38.

12. Werkle-Bergner M. Cortical EEG correlates of successful memory encoding: Implications for lifespan comparisons. Review / M. Werkle-Bergner, V. Müller, Shu-Chen Li, U. Lindenberger // Neuroscience and Biobehavioral Reviews. - 2006. - V. 30. - P. 839-854

Мавромати Татьяна, Филимонова Наталья, Зима Игорь. Половые отличия в активности головного мозга человека при тестировании ассоциативной памяти. В работе исследуется активность головного мозга при запоминании ассоциаций разных типов у мужчин и женщин. Обследуемые (40 людей - 20 женщин и

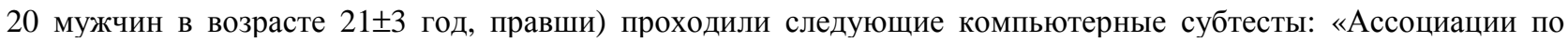
сходству», «Ассоциации по смежности по времени» и «Ассоциации по смежности по пространству». У всех обследуемых регистрировали ЭЭГ до начала обследования и во время проведения тестирования. Установлено, что запоминание ассоциации по сходству у женщин происходило с привлечением слуховой памяти, семантического анализа, интермодальних взаимодействий и создания зрительных образов ассоциативных пар слов, в то время как мужчины запоминали пары слов с помощью их проговаривания. Запоминание ассоциаций по смежности по времени для женщин оказалось наиболее сложным и потребовало привлечения задней ассоциативной коры обоих полушарий. Запоминание ассоциаций по смежности по пространству у мужчин происходило фактически с помощью механизмов их представления и проговаривания, в отличии от женщин, которые, в свою очередь, запоминали указанную информацию с помощью как её образного представления, так и вербального семантического анализа.

Ключевые слова: ассоциативная память, ЭЭГ, активность головного мозга, вербальные ассоциации по сходству, вербальные ассоциации по смежности.

Mavromati Tetiana, Filimonova Nataliya, Zima Igor. Sex differences in the Human Brain Activity During the Associative Memory Testing. In this paper the activity of the brain during memorization of the different types of associations in men and women. The subjects (20 women and 20 men aged $21+/-3$ Year, right-handers) held the following computer subtests «Association by similarity», «Association by contiguity in time» and «Association by contiguity in space». All subjects recorded EEG before the test and during the tests. It was found that the memorization of the similarity associations in women took place with the involvement of the auditory memory, semantic analysis, intermodal interaction and visual images associative word pairs, while the men memorized pairs of words with the help of pronunciation. Memorization of the associations by contiguity in time in women has been the most difficult and required the use of the back of the association cortex of both hemispheres. Memorization of the associations by contiguity in space (spatial) in men happened, factuality, through mechanisms of representation and of pronunciation, as opposed to women, who in turn memorized this information by both its figurative representation, verbal and semantic analysis.

Key words: Associative memory, EEG, activity of the brain, verbal associations by similarity, verbal associations by contiguity.

Стаття надійшла до редколегії 20.09.2015 p.

УДК 611.81:612.13-055.1

Володимир Пшибельський

\section{Особливості стану показників мозкового кровообігу в чоловіків, які зайняті в промисловості}

Проаналізовано та вивчено особливості мозкового кровообігу в осіб чоловічої статі, які зайняті в промисловому виробництві, і тих, котрі проживають у відносно чистих екологічних зонах. Виявлено статистично відмінні значення церебрального кровообігу між двома групами досліджуваних. У групі осіб, зайнятих у

(ㄷ) Пиибельський В., 2015 